\title{
Article \\ Casein Glycomacropeptide: An Alternative Protein Substitute in Tyrosinemia Type I
}

\author{
Anne Daly* ${ }^{\circ}$, Sharon Evans $(\mathbb{D}$, Alex Pinto, Catherine Ashmore and Anita MacDonald \\ Birmingham Women's and Children's Hospital, Birmingham B4 6NH, UK; evanss21@me.com (S.E.); \\ alex.pinto@nhs.net (A.P.); catherine.ashmore@nhs.net (C.A.); anita.macdonald@nhs.net (A.M.) \\ * Correspondence: a.daly3@nhs.net; Tel.: +44-0121-3338024
}

check for updates

Citation: Daly, A.; Evans, S.; Pinto, A.; Ashmore, C.; MacDonald, A. Casein Glycomacropeptide: An Alternative Protein Substitute in Tyrosinemia Type I. Nutrients 2021, 13 , 3224. https://doi.org/10.3390/ nu13093224

Academic Editor: Ebba Nexo

Received: 16 August 2021

Accepted: 14 September 2021

Published: 16 September 2021

Publisher's Note: MDPI stays neutral with regard to jurisdictional claims in published maps and institutional affiliations.

Copyright: (c) 2021 by the authors. Licensee MDPI, Basel, Switzerland. This article is an open access article distributed under the terms and conditions of the Creative Commons Attribution (CC BY) license (https:// creativecommons.org/licenses/by/ $4.0 /)$.
Abstract: Tyrosinemia type I (HTI) is treated with nitisinone, a tyrosine (Tyr) and phenylalanine (Phe)-restricted diet, and supplemented with a Tyr/Phe-free protein substitute (PS). Casein glycomacropeptide (CGMP), a bioactive peptide, is an alternative protein source to traditional amino acids (L-AA). CGMP contains residual Tyr and Phe and requires supplementation with tryptophan, histidine, methionine, leucine, cysteine and arginine. Aims: a 2-part study assessed: (1) the tolerance and acceptability of a low Tyr/Phe CGMP-based PS over 28 days, and (2) its long-term impact on metabolic control and growth over 12 months. Methods: 11 children with HTI were recruited and given a low Tyr/Phe CGMP to supply all or part of their PS intake. At enrolment, weeks 1 and 4, caregivers completed a questionnaire on gastrointestinal symptoms, acceptability and ease of PS use. In study part 1, blood Tyr and Phe were assessed weekly; in part 2, weekly to fortnightly. In parts 1 and 2, weight and height were assessed at the study start and end. Results: Nine of eleven children (82\%), median age 15 years (range 8.6-17.7), took low Tyr/Phe CGMP PS over 28 days; it was continued for 12 months in $n=5$ children. It was well accepted by $67 \%(n=6 / 9)$, tolerated by $100 \%(n=9 / 9)$ and improved gastrointestinal symptoms in 2 children. The median daily dose of protein equivalent from protein substitute was $60 \mathrm{~g} /$ day (range 45-60 g) with a median of $20 \mathrm{~g} /$ day (range 15 to $30 \mathrm{~g}$ ) from natural protein. In part $2(n=5)$, a trend for improved blood Tyr was observed: 12 months pre-study, median Tyr was $490 \mu \mathrm{mol} / \mathrm{L}$ (range 200-600) and Phe $50 \mu \mathrm{mol} / \mathrm{L}$ (range 30-100); in the 12 months taking low Tyr/Phe CGMP PS, median Tyr was $430 \mu \mathrm{mol} / \mathrm{L}$ (range 270-940) and Phe $40 \mu \mathrm{mol} / \mathrm{L}$ (range 20-70). Normal height, weight and BMI z scores were maintained over 12 months. Conclusions: In HTI children, CGMP was well tolerated, with no deterioration in metabolic control or growth when studied over 12 months. The efficacy of CGMP in HTI needs further investigation to evaluate the longer-term impact on blood Phe concentrations and its potential influence on gut microflora

Keywords: tyrosinemia type 1; protein substitute; amino acids; glycomacropeptide

\section{Introduction}

Hereditary Tyrosinemia Type I (HTI), a rare inherited metabolic disorder of tyrosine metabolism, causes abnormal production of toxic metabolites (fumarylacetoacetate, maleylacetoacetate, succinylacetoacetate and succinylacetone), responsible for liver cirrhosis, renal tubular disease and vitamin D resistant rickets [1,2]. Treatment with nitisinone 2-(2nitro-4-trifluoromethylbenzoyl)-1,3-cyclohexanodione (NTBC) prevents the accumulation of these toxic compounds by blocking the pathway at step two in the tyrosine pathway, mimicking HT III deficiency. This causes further elevation of blood tyrosine concentrations. To reduce blood tyrosine to an accepted treatment range of 200 to $400 \mu \mathrm{mol} / \mathrm{L}$ [3], a lifelong phenylalanine/tyrosine-restricted diet supplemented with a phenylalanine/tyrosine-free protein substitute is recommended. Additional phenylalanine supplementation is commonly necessary $[4,5]$.

Traditionally protein substitutes are based on tyrosine/phenylalanine-free amino acids (L-AA), but due to the low prevalence of this condition, choices are limited; they 
are commonly powders or liquids only, with a narrow range of flavor choices. Patient acceptance is poor [6] and failure to take the prescribed dose adversely affects metabolic control and nutritional status [7].

An alternative protein substitute derived from modified casein glycomacropeptide (CGMP), low in tyrosine and phenylalanine but supplemented with additional amino acids, has been developed for HTI. The bioactive properties of CGMP are linked to the sialylated side chains attached to the macropeptide [8], and these are associated with clinical benefits, including improved gut flora [9,10], enhanced immune response [11] and anti-cariogenic properties [12]. A similar modified CGMP has been extensively studied in phenylketonuria (PKU). It is described as less bitter tasting and is linked to improved adherence in children [13-15]. There is also evidence that CGMP may improve growth and body composition in children with PKU [16]. In contrast, it is established that the residual phenylalanine content can lead to a deterioration in metabolic control in children with PKU [17]. There are no publications studying the outcome of patients with HTI when given CGMP as a protein substitute.

This two-part prospective interventional study aimed to investigate the acceptability, growth and metabolic control in a group of children with HTI given low Tyr/Phe CGMP (study product) as part of their protein intake over 12 months.

\section{Materials and Methods}

\subsection{Study Design}

This was a 2-part prospective intervention study (Figure 1).

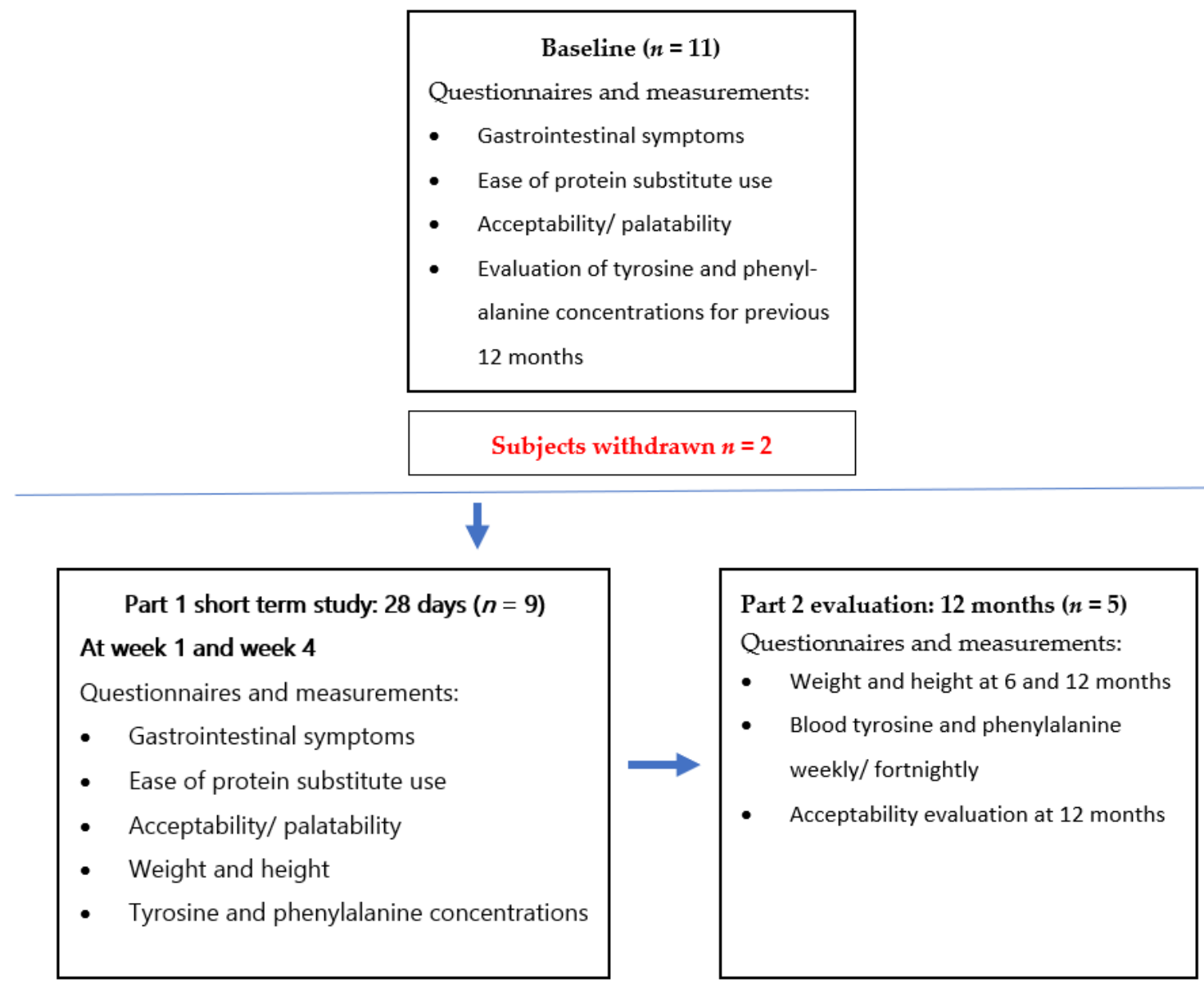

Figure 1. Diagram showing study design. Part 1: a short-term acceptability and tolerance study; Part 2: 12-month follow-up study in HTI children using a study product based on CGMP. 
Part 1: in a 28-day short-term acceptability and tolerance study, children replaced one or more of their usual daily doses of L-AA with the same amount of protein equivalent from the study product. Questionnaires on gastrointestinal tolerance, palatability and ease of use of L-AA and study product were completed by parents at baseline, week 1 and week 4 (see Supplementary Information for questionnaires). Weekly fasting blood samples were taken for tyrosine and phenylalanine. Target blood tyrosine ranges for children were 200 to $400 \mu \mathrm{mol} / \mathrm{L}$ as recommended by an international working group on HTI [3]. Weight and height were measured at baseline and day 28 .

Part 2: an extended follow-up study over 12 months was conducted in a cohort of children with HTI $(n=5)$ who chose to continue to use the study product (low Tyr/Phe CGMP PS). Regular (weekly to fortnightly) blood tyrosine and phenylalanine concentrations were measured. Weight and height were assessed at 6 and 12 months, and body mass index (BMI) was calculated. An acceptability evaluation was completed at the end of 12 months.

\subsection{Subjects}

Inclusion criteria: children diagnosed with HTI, $\geq 5$ years of age and on a tyrosine/phenylalanine restricted diet, supplemented with L-AA and NTBC therapy.

Exclusion criteria: children $<5$ years of age, with a known allergy to milk, fish or soya (ingredients added to CGMP PS), additional co-morbidities (e.g., diabetes), non-adherent with dietary restriction or L-AA or participating in another study.

\subsection{Protein Substitutes Used in the Study}

The study product (Tyr sphere, a test product from Vitaflo International Ltd., Liverpool, $\mathrm{UK}$ ) was a berry-flavored powder containing $11 \mathrm{mg}$ of tyrosine and $36 \mathrm{mg}$ of phenylalanine for each $20 \mathrm{~g}$ protein equivalent. It was reconstituted by adding $120 \mathrm{~mL}$ of water. It contained vitamins, minerals, trace elements and docosahexaenoic acid.

The L-AA supplements were either powders made with water (to a semi-solid consistency) or ready-to-drink liquids, both of which provided 10, 15 or $20 \mathrm{~g}$ of protein equivalent per dose. Products contained vitamins, minerals and trace elements, but docosahexaenoic acid was added to the Tyr Cooler only. Table 1 shows the nutritional profile of protein substitutes used.

\subsection{Anthropometry}

Height was measured using a Harpenden stadiometer (Holtain Ltd., Cyrmych, UK) and weight on calibrated digital scales (Seca, Medical Measuring Systems and Scales, Birmingham, Model 875, UK). Weight was measured to the nearest $0.1 \mathrm{~g}$ and height to the nearest $0.1 \mathrm{~cm}$. All measurements were collected by one dietitian.

\subsection{Blood Tyrosine, Phenylalanine, Succinylacetone and NTBC Concentrations}

For each subject, the median tyrosine and phenylalanine blood concentrations were reviewed for 12 months prior to starting the study and compared with blood tyrosine and phenylalanine results collected during study parts 1 and 2 .

Information on routine biochemistry, plasma succinylacetone and NTBC concentrations were collected from routine clinic appointments.

Trained parents and caregivers collected early morning, weekly or fortnightly fasting blood samples on filter cards, Perkin Elmer 226 (UK standard NBS). All cards had a standard thickness, and blood tyrosine and phenylalanine concentrations were calculated on a $3.2 \mathrm{~mm}$ punch by (MS/MS) tandem mass spectrometry (Waters Xevo TQD, manufactured Wilmslow, Cheshire, UK). They were sent via first class post to Birmingham Children's Hospital laboratory.

\subsection{Natural Protein Intake}

All the children were prescribed a tyrosine/phenylalanine-restricted diet and the estimated median prescribed natural protein intake was $20 \mathrm{~g} /$ day (range 15 to $30 \mathrm{~g}$ ). 


\subsection{Statistical Analysis}

Descriptive statistics were used to analyze the data. Nonparametric paired Wilcoxon t-tests were used to compare anthropometry (weight, height and BMI), blood tyrosine and phenylalanine concentrations between the subjects. A $p$-value $<0.05$ was considered statistically significant (analyzed using Prism GraphPad v 9.0).

Table 1. Nutritional composition of protein substitutes for HTI used in the study.

\begin{tabular}{|c|c|c|c|c|c|}
\hline & \multirow[b]{2}{*}{ Units } & \multirow{2}{*}{$\begin{array}{c}\text { Low } \\
\text { Phe/TyrCGMP } \\
\begin{array}{c}\text { CGMP PS per } 20 \mathrm{~g} \\
\text { PE }\end{array}\end{array}$} & \multicolumn{3}{|c|}{$\begin{array}{l}\text { Phenylalanine/Tyrosine-Free Amino Acid Supplements } \\
\text { (L-AA) }\end{array}$} \\
\hline & & & $\begin{array}{l}\text { Tyr Cooler } \\
20 \mathrm{~g} \text { PE }\end{array}$ & $\begin{array}{l}\text { Tyr Express } 20 \mathrm{~g} \\
\text { PE }\end{array}$ & $\begin{array}{l}\text { Tyr Shake and Go } \\
20 \mathrm{~g} \mathrm{PE}\end{array}$ \\
\hline Manufacturer & & $\begin{array}{l}\text { Vitaflo } \\
\text { International }\end{array}$ & $\begin{array}{l}\text { Vitaflo- } \\
\text { International }\end{array}$ & $\begin{array}{l}\text { Vitaflo- } \\
\text { International }\end{array}$ & Galen Ltd \\
\hline \multicolumn{6}{|c|}{ Macronutrients } \\
\hline \multirow[t]{2}{*}{ Energy } & $\mathrm{kJ}$ & 508 & 549 & 429 & 693 \\
\hline & kcal & 120 & 130 & 101 & 163 \\
\hline Fat & g & 1.6 & 1.6 & 0.07 & $<0.5$ \\
\hline of which saturates & $\mathrm{g}$ & 0.35 & 0.3 & 0 & $<0.5$ \\
\hline of which DHA & $\mathrm{mg}$ & 110 & 134 & NA & NA \\
\hline Carbohydrate & $g$ & 6.3 & 8.9 & 4.7 & 17 \\
\hline of which sugars & g & 1.4 & 5.9 & 0.33 & $<12$ \\
\hline Protein equivalent & g & 20 & 20 & 20 & 20 \\
\hline Fiber & g & 0 & 0 & 0 & 1.7 \\
\hline Salt & g & 0.71 & 0.26 & 0.44 & 0.4 \\
\hline \multicolumn{6}{|c|}{ Vitamins, minerals and micronutrients } \\
\hline Vitamin A & $\mu \mathrm{g} R E$ & 259 & 261 & 283 & 241 \\
\hline Vitamin D & $\mu g$ & 5.0 & 10 & 4.5 & 4.7 \\
\hline Vitamin E & $\operatorname{mg} \alpha \mathrm{TE}$ & 5.3 & 5.2 & 5.3 & 5.0 \\
\hline Vitamin C & $\mathrm{mg}$ & 26 & 37 & 36.7 & 30.5 \\
\hline Vitamin K & $\mu \mathrm{g}$ & 23 & 24 & 34 & 33 \\
\hline Thiamin & $\mathrm{mg}$ & 0.6 & 0.7 & 0.7 & 0.7 \\
\hline Riboflavin & $\mathrm{mg}$ & 0.6 & 0.8 & 0.8 & 0.8 \\
\hline Niacin & $\mathrm{mg}$ & 3.2 & 3.5 & 8.4 & 8.6 \\
\hline Vitamin B6 & $\mathrm{mg}$ & 0.6 & 0.9 & 1.0 & 0.8 \\
\hline Folic Acid & $\mu \mathrm{g}$ & 102 & 101 & 136 & 103 \\
\hline Vitamin B12 & $\mu \mathrm{g}$ & 1.6 & 1.6 & 1.6 & 1.3 \\
\hline Biotin & $\mu \mathrm{g}$ & 13 & 13 & 64 & 52 \\
\hline Pantothenic acid & $\mathrm{mg}$ & 2.0 & 1.9 & 2.7 & 2.4 \\
\hline Choline & $\mathrm{mg}$ & 200 & 200 & 204 & 198 \\
\hline Sodium & mmol & 12 & 4.5 & 7.5 & 7.9 \\
\hline Potassium & mmol & 5.9 & 6.1 & 8.0 & 8.9 \\
\hline Chloride & mmol & 0.2 & 3.9 & 6.9 & 7.9 \\
\hline Calcium & $\mathrm{mg}$ & 399 & 400 & 407 & 371 \\
\hline
\end{tabular}


Table 1. Cont.

\begin{tabular}{|c|c|c|c|c|c|}
\hline & & \multirow{2}{*}{$\begin{array}{c}\text { Low } \\
\text { Phe/TyrCGMP } \\
413\end{array}$} & \multicolumn{3}{|c|}{$\begin{array}{l}\text { Phenylalanine/Tyrosine-Free Amino Acid Supplements } \\
\text { (L-AA) }\end{array}$} \\
\hline Phosphorus & $\mathrm{mg}$ & & 357 & 363 & 293 \\
\hline Magnesium & $\mathrm{mg}$ & 115 & 110 & 128 & 103 \\
\hline Iron & $\mathrm{mg}$ & 7.4 & 7.3 & 7.3 & 6.9 \\
\hline Copper & $\mu g$ & 0.6 & 0.7 & 0.8 & 0.6 \\
\hline Zinc & $\mathrm{mg}$ & 7.4 & 5.6 & 7.3 & 5.7 \\
\hline Manganese & $\mathrm{mg}$ & 0.4 & 0.5 & 1.1 & 1.1 \\
\hline Iodine & $\mu \mathrm{g}$ & 84 & 85 & 86 & 81 \\
\hline Molybdenum & $\mu \mathrm{g}$ & 20 & 23 & 49 & 60 \\
\hline Selenium & $\mu g$ & 30 & 26 & 30 & 28 \\
\hline Chromium & $\mu g$ & 12 & 14 & 30 & 24 \\
\hline \multicolumn{6}{|c|}{ Amino acids $\mathrm{g} / 20 \mathrm{~g}$ protein equivalent } \\
\hline L-Alanine & $\mathrm{g}$ & 0.83 & 1.62 & 1.44 & 1.32 \\
\hline L-Arginine & $\mathrm{g}$ & 1.70 & 1.98 & 1.85 & 1.58 \\
\hline L-Aspartic Acid & $\mathrm{g}$ & 1.31 & 3.06 & 2.86 & 2.75 \\
\hline L-Cystine & $\mathrm{g}$ & 0.24 & 0.73 & 0.69 & 0.74 \\
\hline L-Glutamine & $\mathrm{g}$ & 2.70 & 0.00 & 1.83 & 1.8 \\
\hline Glycine & $\mathrm{g}$ & 2.48 & 1.62 & 1.50 & 2.46 \\
\hline L-Histidine & g & 0.70 & 1.08 & 1.01 & 0.86 \\
\hline L-Isoleucine & $g$ & 1.42 & 1.79 & 1.68 & 1.48 \\
\hline L-Leucine & $\mathrm{g}$ & 3.00 & 2.89 & 2.69 & 2.57 \\
\hline L-Lysine & g & 0.95 & 2.05 & 1.91 & 1.58 \\
\hline L-Methionine & $\mathrm{g}$ & 0.28 & 0.47 & 0.43 & 0.40 \\
\hline L-Phenylalanine & $g$ & $\begin{array}{c}0.036 \\
(36 \mathrm{mg})\end{array}$ & 0.00 & 0.00 & 0.00 \\
\hline L-Proline & $\mathrm{g}$ & 1.60 & 1.65 & 1.55 & 1.72 \\
\hline L-Serine & $g$ & 1.01 & 1.27 & 1.18 & 1.00 \\
\hline L-Threonine & $\mathrm{g}$ & 2.29 & 1.39 & 1.29 & 1.72 \\
\hline L-Tryptophan & $\mathrm{g}$ & 0.40 & 0.57 & 0.54 & 0.46 \\
\hline L-Tyrosine & $\mathrm{g}$ & $\begin{array}{c}<0.011 \\
(11 \mathrm{mg})\end{array}$ & 0.00 & 0.00 & 0.00 \\
\hline L-Valine & $\mathrm{g}$ & 1.14 & 1.97 & 1.83 & 1.75 \\
\hline
\end{tabular}

Legend: DHA docosahexaenoic acid PE, protein equivalent; low Tyr/Phe CGMP, low tyrosine and phenylalanine casein glycomacropeptide (study product); L-AA phenylalanine/tyrosine-free amino acid supplements, Tyr cooler, Tyr express (Vitaflo International); Tyr Shake and Go (Gaelan Ltd. Craigavon, Northern Island, UK), mg milligram of phenylalanine and tyrosine per $20 \mathrm{~g}$ of protein equivalent.

\subsection{Ethical Approval}

The study was approved by the Northwest Liverpool East Research Ethics committee and granted a favorable ethical opinion, reference number 19/NW/0390 and IRAS (Integrated Research Application System) MCT-TYRS-2019-03-04. Written informed consent was obtained for all subjects from at least one caregiver with parental responsibility, and written consent was obtained from subjects if appropriate for their age and level of understanding. 


\section{Results}

\subsection{Subjects}

In part 1, 11 children with HTI were recruited, and nine (4 females, 5 males) completed part 1 . The median age was 15 years, range ( 8.6 to 17.7 years). Sixty-seven percent $(n=6)$ completed the full 28 days, three children completed up to 25 days and two withdrew on days 1 and 17.

Part 2, five children participated in the study part 2 . The median age was 15.3 years (range 8.6 to15.4 years). There were three girls and two boys (Table 2).

Table 2. Subject characteristics and numbers recruited to study parts 1 and 2.

\begin{tabular}{|c|c|c|c|c|c|c|c|}
\hline \multicolumn{8}{|c|}{ PART 1 SUBJECTS SHORT TERM EVALUATION OVER 28 DAYS } \\
\hline Subject & Age (years) & Sex & $\begin{array}{c}\text { Number of } \\
\text { Estimated Protein } \\
\text { Exchanges }\end{array}$ & Ethnicity & $\begin{array}{c}\text { \% (Number) of } \\
\text { Days } \\
\text { Completed in Part } 1\end{array}$ & $\begin{array}{c}\text { Subjects } \\
\text { Completing } \\
\text { Part } 2\end{array}$ & $\begin{array}{l}\text { \% of Protein } \\
\text { Equivalent } \\
\text { from CGMP }\end{array}$ \\
\hline 1 & 17.1 & M & 28 & British Asian & $89 \%(25)$ & No & $100 \%$ \\
\hline 2 & 10.5 & M & 25 & British Asian & $86 \%(24)$ & No & $33 \%$ \\
\hline 3 & 17.7 & $\mathrm{~F}$ & 26 & Caucasian & $100 \%(28)$ & No & $33 \%$ \\
\hline 4 & 14.7 & M & 16 & Caucasian & $64 \%(18)$ & No & $33 \%$ \\
\hline 5 & 5.3 & $\mathrm{~F}$ & 12 & Caucasian & $\begin{array}{c}1 \\
\text { Withdrawn }\end{array}$ & No & $44 \%$ \\
\hline 6 & 15.5 & M & 25 & British Asian & $\begin{array}{c}17 \\
\text { Withdrawn }\end{array}$ & No & $33 \%$ \\
\hline \multicolumn{8}{|c|}{ PART 2 SUBJECTS FOLLOWED UP FOR 12 MONTHS } \\
\hline 7 & 15.3 & $\mathrm{~F}$ & 24 & Caucasian & $100 \%(28)$ & Yes & $100 \%$ \\
\hline 8 & 15.4 & $\mathrm{M}$ & 30 & Arabic & $100 \%(28)$ & Yes & $100 \%$ \\
\hline 9 & 13.9 & $\mathrm{M}$ & 20 & British Asian & $100 \%$ (28) & Yes & $100 \%$ \\
\hline 10 & 15.0 & F & 20 & British Asian & $100 \%$ (28) & Yes & $100 \%$ \\
\hline 11 & 8.6 & F & 20 & British Asian & $100 \%(28)$ & Yes & $100 \%$ \\
\hline
\end{tabular}

Legend: Subjects 5 and 6 withdrew from the study, F female, M male. CGMP PS, low tyrosine and phenylalanine casein glycomacropeptide (study product).

\subsection{Subject Withdrawal}

One child (number 5) only completed study day one and did not progress any further, as the study product was disliked. Another child (number 6) developed viral gastritis and was unable to complete the study after day 17. A further four children chose to stop the study product at 28 days, preferring their original L-AA supplements.

\subsection{Protein Substitute Type}

Prior to starting the study, all children were taking L-AA supplements with added vitamins and minerals. Eight children were taking Tyr Cooler 20 (Vitaflo Int, Liverpool, UK), and three were taking powdered preparations: Tyr Express 20, (Vitaflo Int, Liverpool, UK), $(n=1)$, Tyr gel (Vitaflo Int. Liverpool, UK) $(n=1)$ and Tyr Shake and Go (Galen Ltd.) $(n=1)$.

\section{Median Protein Substitute Intake in Part 1 and 2}

In part $1(n=9)$, the median daily dose of protein equivalent from protein substitute was $60 \mathrm{~g} /$ day (range 45 to $60 \mathrm{~g}$ ), providing $1.2 \mathrm{~g}$ protein equivalent/ $\mathrm{kg}$ body weight (range 0.8 to $2.4 \mathrm{~g} / \mathrm{kg}$ ). The median amount of prescribed natural protein was $20 \mathrm{~g} /$ day (range 15 to $30 \mathrm{~g}$ ), and no child was taking phenylalanine supplementation. In this short-term study, six children completely replaced their entire prescribed L-AA with the study product, while 
the remaining children changed one dose ( $20 \mathrm{~g} /$ day protein equivalent) of L-AA for the study product and took two doses of L-AA ( $40 \mathrm{~g} /$ day protein equivalent).

In part $2(n=5)$, the intake of protein equivalent from the study product was $60 \mathrm{~g} /$ day, with all children completely replacing their L-AA supplement with low Tyr/Phe CGMP PS. The median amount of protein equivalent was $1.0 \mathrm{~g} / \mathrm{kg}$ (range 0.8 to $2.4 \mathrm{~g} / \mathrm{kg}$ ). The median intake of natural protein was estimated at $20 \mathrm{~g} /$ day (range 19 to $30 \mathrm{~g}$ ).

\subsection{NTBC and Concurrent Medications}

All children took NTBC once daily. In parts $1(n=9)$ and $2(n=5)$, the median intake was $0.8 \mathrm{mg} / \mathrm{kg}$ (range 0.5 to $1.2 \mathrm{mg} / \mathrm{kg}$ ), and no other medications were prescribed. Plasma succinylacetone concentrations were all $<0.5 \mu \mathrm{mol} / \mathrm{L}$ (reference $<0.5 \mu \mathrm{mol} / \mathrm{L}$ ) [18].

\subsection{Tyrosine and Phenylalanine Blood Concentrations}

There were no statistically significant changes in blood tyrosine or phenylalanine concentrations over study part $1(n=9)$ or $2(n=5)$. In part 1 , median blood tyrosine for the 12 months pre-study were $393 \mu \mathrm{mol} / \mathrm{L}$ (range 200-600 $\mu \mathrm{mol} / \mathrm{L}$ ) and post 28 days, $385 \mu \mathrm{mol} / \mathrm{L}$ (range 200-600 $\mu \mathrm{mol} / \mathrm{L})(n=9)$. For the children who extended the study for 12 months $(n=5)$ : median tyrosine pre-study was $490 \mu \mathrm{mol} / \mathrm{L}$ (range 200-600 $\mu \mathrm{mol} / \mathrm{L}$ ), and for the 12 months continuation study, $430 \mu \mathrm{mol} / \mathrm{L}$ (range 200-600 $\mu \mathrm{mol} / \mathrm{L}$ ) (Table 3). Three of five children had an improvement in blood tyrosine, although four remained above the target therapeutic range $(200-400 \mu \mathrm{mol} / \mathrm{L})$.

Table 3. Median tyrosine and phenylalanine blood concentrations (range) for study part 1, 28 days and part 2, follow-up over 12 months when taking the study protein substitute \pm amino acid supplements.

\begin{tabular}{|c|c|c|c|c|c|c|}
\hline $\begin{array}{c}\text { Subjects } \\
\quad n=9\end{array}$ & $\begin{array}{l}\text { Median Tyr } \\
\text { (Range) } \\
\mu \mathrm{mol} / \mathrm{L} \\
12 \text { Months } \\
\text { Pre-Study }\end{array}$ & $\begin{array}{c}\text { Median Tyr } \\
\text { (Range) } \\
\mu m o l / L \text { During } \\
28 \text { Day Study }\end{array}$ & $\begin{array}{c}\begin{array}{c}\text { Median Tyr } \\
\text { (Range) }\end{array} \\
\mu \mathrm{mol} / \mathrm{L} \text { for } 12 \\
\text { Months Using } \\
\text { Study Product }\end{array}$ & $\begin{array}{l}\text { Median Phe } \\
\text { (Range) } \\
\mu \text { mol/L } \\
12 \text { Months } \\
\text { Pre-Study }\end{array}$ & $\begin{array}{l}\text { Median Phe } \\
\text { (Range) } \\
\mu \mathrm{mol} / \mathrm{L} \text { during } \\
28 \text { Day Study }\end{array}$ & $\begin{array}{l}\text { Median Phe } \\
\text { (Range) } \mu \mathrm{mol} / \mathrm{L} \\
\text { for } 12 \text { Months } \\
\text { Using Study } \\
\text { Product }\end{array}$ \\
\hline 1 & $\begin{array}{c}312 \\
(200-400)\end{array}$ & $\begin{array}{c}330 \\
(200-400)\end{array}$ & - & $\begin{array}{c}45 \\
(30-100)\end{array}$ & $\begin{array}{c}40 \\
(30-100)\end{array}$ & - \\
\hline 2 & $\begin{array}{c}338 \\
(200-400)\end{array}$ & $\begin{array}{c}375 \\
(200-400)\end{array}$ & - & $\begin{array}{c}30 \\
(30-60)\end{array}$ & $\begin{array}{c}40 \\
(30-60)\end{array}$ & - \\
\hline 3 & $\begin{array}{c}315 \\
(290-400)\end{array}$ & $\begin{array}{c}324 \\
(290-400)\end{array}$ & - & $\begin{array}{c}45 \\
(30-60)\end{array}$ & $\begin{array}{c}55 \\
(50-60)\end{array}$ & - \\
\hline 4 & $\begin{array}{c}428 \\
(200-440)\end{array}$ & $\begin{array}{c}415 \\
(200-430)\end{array}$ & - & $\begin{array}{c}40 \\
(30-60)\end{array}$ & $\begin{array}{c}40 \\
(30-60)\end{array}$ & - \\
\hline 7 & $\begin{array}{c}393 \\
(200-400)\end{array}$ & $\begin{array}{c}375 \\
(200-400)\end{array}$ & $\begin{array}{c}430 \\
(290-660)\end{array}$ & $\begin{array}{c}55 \\
(30-60)\end{array}$ & $\begin{array}{c}40 \\
(30-60)\end{array}$ & $\begin{array}{c}40 \\
(30-50)\end{array}$ \\
\hline 8 & $\begin{array}{c}490 \\
(200-500)\end{array}$ & $\begin{array}{c}460 \\
(200-490)\end{array}$ & $\begin{array}{c}430 \\
(270-710)\end{array}$ & $\begin{array}{c}50 \\
(30-100)\end{array}$ & $\begin{array}{c}50 \\
(30-100)\end{array}$ & $\begin{array}{c}40 \\
(30-50)\end{array}$ \\
\hline 9 & $\begin{array}{c}535 \\
(200-600)\end{array}$ & $\begin{array}{c}495 \\
(200-600)\end{array}$ & $\begin{array}{c}330 \\
(270-380)\end{array}$ & $\begin{array}{c}55 \\
(30-60)\end{array}$ & $\begin{array}{c}50 \\
(30-60)\end{array}$ & $\begin{array}{c}30 \\
(30-40)\end{array}$ \\
\hline 10 & $\begin{array}{c}370 \\
(200-600)\end{array}$ & $\begin{array}{c}445 \\
(200-600)\end{array}$ & $\begin{array}{c}570 \\
(320-940)\end{array}$ & $\begin{array}{c}30 \\
(30-60)\end{array}$ & $\begin{array}{c}30 \\
(30-60)\end{array}$ & $\begin{array}{c}50 \\
(30-70)\end{array}$ \\
\hline 11 & $\begin{array}{c}525 \\
(200-600)\end{array}$ & $\begin{array}{c}385 \\
(200-400)\end{array}$ & $\begin{array}{c}490 \\
(290-830)\end{array}$ & $\begin{array}{c}50 \\
(30-70)\end{array}$ & $\begin{array}{c}60 \\
(30-70)\end{array}$ & $\begin{array}{c}30 \\
(20-60)\end{array}$ \\
\hline Median & $\begin{array}{c}393 \\
(200-600)\end{array}$ & $\begin{array}{c}385 \\
(200-600)\end{array}$ & $\begin{array}{c}430 \\
(270 \text { to } 940)\end{array}$ & $\begin{array}{c}45 \\
(30-100)\end{array}$ & $\begin{array}{c}40 \\
(30-100)\end{array}$ & $\begin{array}{c}40 \\
(20 \text { to } 70)\end{array}$ \\
\hline
\end{tabular}

Median phenylalanine concentrations were all $\geq 40 \mu \mathrm{mol} / \mathrm{L}$ (range $30-100 \mu \mathrm{mol} / \mathrm{L}$ ) (suggested reference range $>50 \mu \mathrm{mol} / \mathrm{L}$ ) [19]. 


\subsection{Routine Biochemistry}

Routine biochemistry measured at regular clinic reviews showed no abnormal clinical findings for liver (including clotting screen) or renal function tests, which included renal tubular phosphate reabsorption, urine creatinine, calcium and phosphate, microalbumin, urine protein, retinol-binding protein and electrolytes. In addition to routine liver function tests (LFTs), alpha-fetoprotein was measured and was within the reference range $(1-10 \mathrm{Ku} / \mathrm{L}$ as measured by Roche E601).

\subsection{Anthropometry}

In part $1(n=9)$, height, weight, and BMI z-scores remained unchanged. Median $\mathrm{z}$-scores for height were -0.5 (range -2.9 to 0.8 ), weight, -0.3 (range -1.7 to 1.1 ) and BMI, 0 (range -2.0 to 2.5). Anthropometry is described in Figure 2 for $n=5$ children who continued on the study product. After 12 months, height z-scores were improved (median $\mathrm{z}$ score -0.3 ) but was not statistically significant and fell within the population norm.

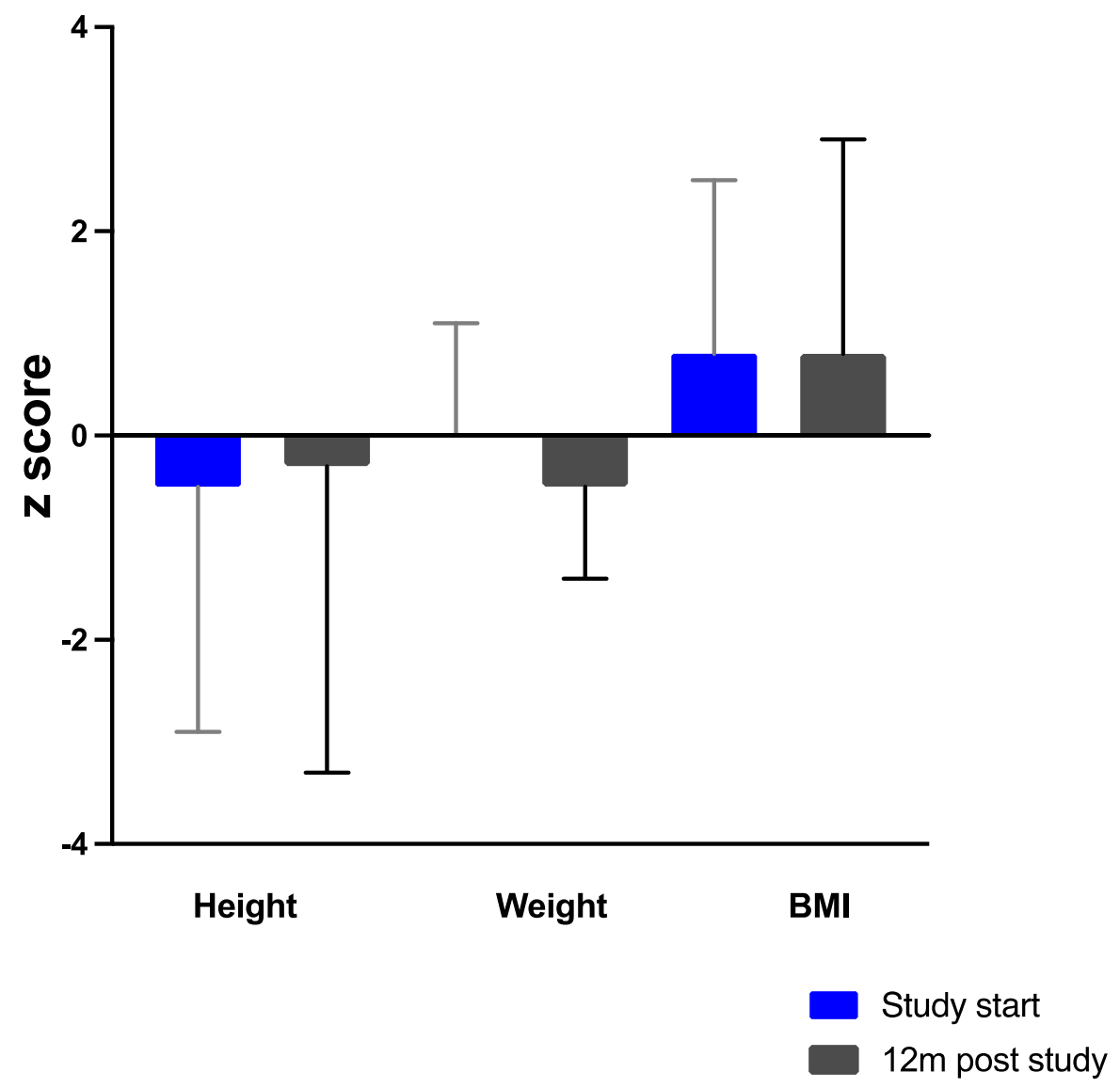

Figure 2. Median height, weight and BMI z-scores for $n=5$ children at the start and end of the 12 months of using the study product.

\subsection{Gastrointestinal Tolerance}

Pre-study: $n=3$ had abdominal discomfort, $n=3$ heartburn, and $n=2$ nausea. One child had a long history of constipation and abdominal pain and was given laxatives, and a further child had a longstanding problem with abdominal pain, which had been extensively investigated. Throughout study parts 1 and 2, there were no significant gastrointestinal problems with the resolution of existing gastrointestinal symptoms for these two children. All other children remained as baseline, with no gastrointestinal disturbances reported. 


\subsection{Palatability}

In part 1,6 of $9(67 \%)$ children who completed at least 24 of the 28-day assessment rated the taste of the study product as favorable, $n=3(33 \%)$ were unsure (they neither liked/disliked the study product) but preferred to take their original L-AA supplement post-trial. Seven of nine $(78 \%)$ children rated the smell favorable.

\subsection{Ease of Preparation}

At the end of study part 1 , one teenager $(17 \mathrm{y})$ chose to continue taking a ready-todrink L-AA supplement as it required no preparation. For the remaining children who preferred the study product, preparation was not a barrier to adherence.

\section{Discussion}

This is the first report to describe the use of a protein substitute based on CGMP in a group of mostly teenagers with HTI. Prior to study commencement, they struggled with protein substitute adherence. Despite the practical difficulties of preparing the study product, $67 \%(n=6)$ accepted the new product in study part 1 , and $55 \%(n=5)$ continued CGMP for 12 months, with $60 \%(n=3)$ improving their adherence as measured by tyrosine and phenylalanine concentrations.

The gut function was noticeably improved in two children, one having a long history of abdominal discomfort and the other chronic constipation. These symptoms abated within seven days of starting the product, and both children took all protein substitutes as CGMP. The role of CGMP in modulating gut microbiota and having a prebiotic activity is favorable, although this has not been studied in PKU or HTI subjects on CGMP $[9,20]$.

The pharmacological actions of protein substitutes are often underestimated, but they are of critical importance in influencing clinical outcomes. They provide a source of essential nitrogen necessary to meet physiological and cellular metabolic functions: improving immunology [21] and allowing normal growth [22]. Biochemically, they provide large neutral amino acids (LNAA), which are competitively transported across the blood brain barrier altering brain neurochemistry $[23,24]$. In a HTI animal model, mice treated with NTBC \pm diet had increased plasma and brain tyrosine and lower phenylalanine concentrations, with serotonin significantly negatively correlated with tyrosine concentrations [25]. Aromatic amino acids in the brain function as precursors for monoamine neurotransmitters; tryptophan producing serotonin and tyrosine producing dopamine, norepinephrine, epinephrine. Neurocognitive impairments have been described with increasing frequency in HTI [26-29], and in this study group, three required extra learning support through educational health care plans (EHCP). Although the exact pathophysiology of this neurodegeneration is unknown, some authors suggest the ratio and balance of LNAA are responsible, while others suggest elevated tyrosine concentrations lead to oxidative damage of the cerebral cortex [27]. Whilst a tyrosine and phenylalanine restricted diet supplemented with protein substitute lowers the brain tyrosine, it is not normalized. In HTI, both Thimm and Naio $[27,30]$ have suggested possible serotonin deficiency as a cause of decreased neurocognition. Naoi demonstrated that high brain tyrosine concentrations inhibited both tyrosine and tryptophan hydroxylase, the rate-limiting enzyme in serotonin deficiency. Thimm measured cerebral spinal fluid, suggesting serotonin deficiency. In rats, high brain tyrosine concentrations have been considered neurotoxic, resulting in oxidative stress, DNA damage and altered mitochondrial energy changes.

The action of a protein substitute based on CGMP may bring additional benefits as it is a rich source of both LNAA (particularly threonine and isoleucine) and sialic acid. This nine-carbon sugar is a structural and functional component of brain gangliosides and has been shown to correlate with the amounts of docosahexaenoic acid (DHA) and total long-chain polyunsaturated fatty acids in the ceramide tail of brain gangliosides [8]. However, the nutritional and biological roles of sialic acid are not fully understood, but in the developing brain, they appear to make an important contribution to the neurological and intellectual outcome. Their potential benefits on amino acid disorders, in which 
there are disturbances in amino acid transport affecting brain function, warrant further investigation.

At the start and end of the CGMP 12-month study, median height z-scores showed a non-significant improvement, remaining $<0$ but within the population norm. The evidence on long-term growth in children with HT1 has rarely been reported. A nationwide study from Finland reported low median adult heigh z-scores in both transplanted and NTBCtreated subjects [31]. In contrast, a retrospective study from Birmingham showed an improvement in height $\mathrm{z}$-scores from 8 years of age, reaching population standards by 16 years of age [32].

Lower concentrations of phenylalanine with phenylalanine deficiency are a persistent finding in HTI [5,33]. CGMP contains residual amounts of both phenylalanine and tyrosine, and this additional phenylalanine may be beneficial in helping sustain phenylalanine concentrations. After 12 months of using the study product, 3 of the $5(60 \%)$ children had a median phenylalanine concentration of $\geq 40 \mu \mathrm{mol} / \mathrm{L}$ and two (subjects 9 and 11) had median phenylalanine concentrations that met recommended clinical target ranges of $\geq 30 \mu \mathrm{mol} / \mathrm{L}$. There is evidence to suggest phenylalanine concentrations should be $\geq 50 \mu \mathrm{mol} / \mathrm{L}$ if measured as a fasting sample in the morning to prevent daytime phenylalanine deficiency [19]. Interestingly, neither the residual phenylalanine (108 mg per day) or tyrosine (33 mg per day) influenced the blood tyrosine or phenylalanine concentrations. This contrasted with the residual phenylalanine in CGMP and its effect on blood phenylalanine control in children with PKU [17].

There are limitations to this study. HTI is a rare disorder with no single center having a large population of subjects. Therefore, we studied only a small number of children with HTI, and although this group of children avoided high protein food choices, natural protein intake was only approximated. Neither tyrosine or phenylalanine concentrations were systematically monitored in study part 2 . Fifty-six percent $(n=5 / 9)$ of children continued the study product, with the remainder continuing their original protein substitute, demonstrating the need for variety to meet the needs of a small but clinically vulnerable population.

\section{Conclusions}

The CGMP protein substitute designed for use in HTI was well accepted, with no deterioration in metabolic control or growth in a small group of patients. The potential longterm benefits of using a bioactive protein substitute on gut microbiota and phenylalanine concentrations in this group of subjects need to be systematically investigated, as it appears that both gut function and phenylalanine concentrations could be improved.

Supplementary Materials: The following are available online at https:/ / www.mdpi.com/article/10 $.3390 /$ nu13093224/s1, Table S1: Pre study gastrointestinal symptoms, Table S2: Week 1 gastrointestinal symptoms using study product, Table S3: Week 4 gastrointestinal symptoms using study product, Table S4: Palatability Likert scale.

Author Contributions: A.D. and A.M. were involved in the project design, collection of data, data analysis and writing of the manuscript. A.D., A.P., C.A., S.E. and A.M. were involved in the interpretation of data, critical revisions of the paper for important intellectual content and final approval of the version submitted for publication. All authors have read and agreed to the published version of the manuscript.

Funding: This study was supported by Vitaflo International Ltd. The sponsors had no role in the design, writing, execution or interpretation of the results.

Institutional Review Board Statement: This project was registered with the ethics committee number 19/NW/0390 and IRAS (Integrated Research Application System) MCT-TYRS-2019-03-04.

Informed Consent Statement: Informed consent was obtained from all subjects involved in the study. 
Data Availability Statement: The data presented in this study are available on request from the corresponding author.

Conflicts of Interest: A.D. has received research funding and financial support from Nutricia and Vitaflo to attend study days and conferences; Vitaflo has funded a $\mathrm{PhD}$, advisory member for APR. A.P. has received an educational grant from Cambrooke Therapeutics and grants from Vitaflo, Nutricia, Merck Serono, Biomarin and Mevalia to attend scientific meetings. C.A. has received financial support from Nutricia and Vitaflo to attend study days and conferences. S.E. has received research funding from Nutricia and financial support from Nutricia and Vitaflo to attend study days and conferences. A.M. has received research funding and honoraria from Nutricia, Vitaflo International and Merck Serono. She is a member of the European Nutritionist Expert Panel (Biomarin), a member of the Sapropterin Advisory Board (Biomarin), a member of the advisory board entitled ELEMENT (Danone-Nutricia) and a member of APR.

\section{References}

1. Baber, M.D. A case of congenital cirrhosis of the liver with renal tubular defects akin to those in the Fanconi syndrome. Arch. Dis. Child. 1956, 31, 335-339. [CrossRef]

2. Van Spronsen, F.J.; van Rijn, M.; Meyer, U.; Das, A.M. Dietary Considerations in Tyrosinemia Type I. Adv. Exp. Med. Biol 2017, 959, 197-204. [CrossRef]

3. Chakarapani, A.; Gissen, P.; McKiernan, P. Disorders of Tyrosine Metabolism. In Inborn Metabolic Diseases, 5th ed.; Saudubray, J.M., van den Berghe, G., Walter, J., Eds.; Springer: Berlin/Heidelberg, Germany, 2012; pp. 275-276.

4. Van Ginkel, W.G.; van Reemst, H.E.; Kienstra, N.S.; Daly, A.; Rodenburg, I.L.; MacDonald, A.; Burgerhof, J.G.M.; de Blaauw, P.; van de Krogt, J.; Santra, S.; et al. The Effect of Various Doses of Phenylalanine Supplementation on Blood Phenylalanine and Tyrosine Concentrations in Tyrosinemia Type 1 Patients. Nutrients 2019, 11, 2816. [CrossRef]

5. Wilson, C.J.; Van Wyk, K.G.; Leonard, J.V.; Clayton, P.T. Phenylalanine supplementation improves the phenylalanine profile in tyrosinaemia. J. Inherit. Metab. Dis. 2000, 23, 677-683. [CrossRef] [PubMed]

6. MacDonald, A.; van Rijn, M.; Feillet, F.; Lund, A.M.; Bernstein, L.; Bosch, A.M.; Gizewska, M.; van Spronsen, F.J. Adherence issues in inherited metabolic disorders treated by low natural protein diets. Ann. Nutr. Metab. 2012, 61, 289-295. [CrossRef] [PubMed]

7. Green, B.; Browne, R.; Firman, S.; Hill, M.; Rahman, Y.; Kaalund Hansen, K.; Adam, S.; Skeath, R.; Hallam, P.; Herlihy, I.; et al. Nutritional and Metabolic Characteristics of UK Adult Phenylketonuria Patients with Varying Dietary Adherence. Nutrients 2019, 11, 2459. [CrossRef] [PubMed]

8. Wang, B.; Brand-Miller, J. The role and potential of sialic acid in human nutrition. Eur. J. Clin. Nutr. 2003, 57, 1351-1369. [CrossRef]

9. Ntemiri, A.; Chonchuir, F.N.; O'Callaghan, T.F.; Stanton, C.; Ross, R.P.; O’Toole, P.W. Glycomacropeptide Sustains Microbiota Diversity and Promotes Specific Taxa in an Artificial Colon Model of Elderly Gut Microbiota. J. Agric. Food Chem. 2017, 65, 1836-1846. [CrossRef]

10. Ortega-Gonzalez, M.; Capitan-Canadas, F.; Requena, P.; Ocon, B.; Romero-Calvo, I.; Aranda, C.; Suarez, M.D.; Zarzuelo, A.; Sanchez de Medina, F.; Martinez-Augustin, O. Validation of bovine glycomacropeptide as an intestinal anti-inflammatory nutraceutical in the lymphocyte-transfer model of colitis. Br. J. Nutr. 2014, 111, 1202-1212. [CrossRef]

11. Otani, H.; Monnai, M.; Kawasaki, Y.; Kawakami, H.; Tanimoto, M. Inhibition of mitogen-induced proliferative responses of lymphocytes by bovine kappa-caseinoglycopeptides having different carbohydrate chains. J. Dairy Res. 1995, 62, 349-357. [CrossRef]

12. Aimutis, W.R. Bioactive properties of milk proteins with particular focus on anticariogenesis. J. Nutr. 2004, 134, 989S-995S. [CrossRef] [PubMed]

13. Lim, K.; van Calcar, S.C.; Nelson, K.L.; Gleason, S.T.; Ney, D.M. Acceptable low-phenylalanine foods and beverages can be made with glycomacropeptide from cheese whey for individuals with PKU. Mol. Genet. Metab. 2007, 92, 176-178. [CrossRef] [PubMed]

14. Ney, D.M.; Gleason, S.T.; van Calcar, S.C.; MacLeod, E.L.; Nelson, K.L.; Etzel, M.R.; Rice, G.M.; Wolff, J.A. Nutritional management of PKU with glycomacropeptide from cheese whey. J. Inherit. Metab. Dis. 2009, 32, 32-39. [CrossRef]

15. Pena, M.J.; Pinto, A.; Daly, A.; MacDonald, A.; Azevedo, L.; Rocha, J.C.; Borges, N. The Use of Glycomacropeptide in Patients with Phenylketonuria: A Systematic Review and Meta-Analysis. Nutrients 2018, 10, 1794. [CrossRef] [PubMed]

16. Daly, A.; Hogler, W.; Crabtree, N.; Shaw, N.; Evans, S.; Pinto, A.; Jackson, R.; Strauss, B.J.; Wilcox, G.; Rocha, J.C.; et al. Growth and Body Composition in PKU Children-A Three-Year Prospective Study Comparing the Effects of L-Amino Acid to Glycomacropeptide Protein Substitutes. Nutrients 2021, 13, 1323. [CrossRef]

17. Daly, A.; Evans, S.; Chahal, S.; Santra, S.; MacDonald, A. Glycomacropeptide in children with phenylketonuria: Does its phenylalanine content affect blood phenylalanine control? J. Hum. Nutr. Diet. 2017, 30, 515-523. [CrossRef]

18. Chinsky, J.M.; Singh, R.; Ficicioglu, C.; van Karnebeek, C.D.M.; Grompe, M.; Mitchell, G.; Waisbren, S.E.; Gucsavas-Calikoglu, M.; Wasserstein, M.P.; Coakley, K.; et al. Diagnosis and treatment of tyrosinemia type I: A US and Canadian consensus group review and recommendations. Genet. Med. 2017, 19, 1380. [CrossRef] 
19. Van Dam, E.; Daly, A.; Venema-Liefaard, G.; van Rijn, M.; Derks, T.G.J.; McKiernan, P.J.; Rebecca Heiner-Fokkema, M.; MacDonald, A.; van Spronsen, F.J. What Is the Best Blood Sampling Time for Metabolic Control of Phenylalanine and Tyrosine Concentrations in Tyrosinemia Type 1 Patients? JIMD Rep. 2017, 36, 49-57. [CrossRef]

20. Sawin, E.A.; De Wolfe, T.J.; Aktas, B.; Stroup, B.M.; Murali, S.G.; Steele, J.L.; Ney, D.M. Glycomacropeptide is a prebiotic that reduces Desulfovibrio bacteria, increases cecal short-chain fatty acids, and is anti-inflammatory in mice. Am. J. Physiol. Gastrointest. Liver Physiol. 2015, 309, G590-G601. [CrossRef]

21. Friedman, M.; Levin, C.E. Nutritional and medicinal aspects of D-amino acids. Amino Acids 2012, 42, 1553-1582. [CrossRef]

22. Acosta, P.B.; Yannicelli, S.; Singh, R.; Mofidi, S.; Steiner, R.; DeVincentis, E.; Jurecki, E.; Bernstein, L.; Gleason, S.; Chetty, M.; et al. Nutrient intakes and physical growth of children with phenylketonuria undergoing nutrition therapy. J. Am. Diet. Assoc. 2003, 103, 1167-1173. [CrossRef]

23. Pardridge, W.M. Blood-brain barrier carrier-mediated transport and brain metabolism of amino acids. Neurochem. Res. 1998, 23, 635-644. [CrossRef]

24. Weglage, J.; Bramswig, J.H.; Koch, H.G.; Karassalidou, S.; Ullrich, K. Growth in patients with phenylketonuria. Eur. J. Pediatr. 1994, 153, 537-538. [CrossRef]

25. Van Ginkel, W.G.; van Vliet, D.; van der Goot, E.; Faassen, M.; Vogel, A.; Heiner-Fokkema, M.R.; van der Zee, E.A.; van Spronsen, F.J. Blood and Brain Biochemistry and Behaviour in NTBC and Dietary Treated Tyrosinemia Type 1 Mice. Nutrients 2019, 11, 2486. [CrossRef]

26. Masurel-Paulet, A.; Poggi-Bach, J.; Rolland, M.O.; Bernard, O.; Guffon, N.; Dobbelaere, D.; Sarles, J.; de Baulny, H.O.; Touati, G. NTBC treatment in tyrosinaemia type I: Long-term outcome in French patients. J. Inherit. Metab. Dis. 2008, 31, 81-87. [CrossRef]

27. Thimm, E.; Herebian, D.; Assmann, B.; Klee, D.; Mayatepek, E.; Spiekerkoetter, U. Increase of CSF tyrosine and impaired serotonin turnover in tyrosinemia type I. Mol. Genet. Metab. 2011, 102, 122-125. [CrossRef] [PubMed]

28. Van Ginkel, W.G.; Jahja, R.; Huijbregts, S.C.; Daly, A.; MacDonald, A.; De Laet, C.; Cassiman, D.; Eyskens, F.; Korver-Keularts, I.M.; Goyens, P.J.; et al. Neurocognitive outcome in tyrosinemia type 1 patients compared to healthy controls. Orphanet J. Rare Dis. 2016, 11, 87. [CrossRef] [PubMed]

29. Van Ginkel, W.G.; Rodenburg, I.L.; Harding, C.O.; Hollak, C.E.M.; Heiner-Fokkema, M.R.; van Spronsen, F.J. Long-Term Outcomes and Practical Considerations in the Pharmacological Management of Tyrosinemia Type 1. Paediatr. Drugs 2019, 21, 413-426. [CrossRef] [PubMed]

30. Naoi, M.; Maruyama, W.; Takahashi, T.; Ota, M.; Parvez, H. Inhibition of tryptophan hydroxylase by dopamine and the precursor amino acids. Biochem. Pharm. 1994, 48, 207-211. [CrossRef] [PubMed]

31. Aarela, L.; Hiltunen, P.; Soini, T.; Vuorela, N.; Huhtala, H.; Nevalainen, P.I.; Heikinheimo, M.; Kivela, L.; Kurppa, K. Type 1 tyrosinemia in Finland: A nationwide study. Orphanet J. Rare Dis. 2020, 15, 281. [CrossRef] [PubMed]

32. Yilmaz, O.; Daly, A.; Pinto, A.; Ashmore, C.; Evans, S.; Gupte, G.; Santra, S.; Preece, M.A.; McKiernan, P.; Kitchen, S.; et al. Natural Protein Tolerance and Metabolic Control in Patients with Hereditary Tyrosinaemia Type 1. Nutrients 2020, 12, 1148. [CrossRef]

33. Van Vliet, D.; van Dam, E.; van Rijn, M.; Derks, T.G.; Venema-Liefaard, G.; Hitzert, M.M.; Lunsing, R.J.; Heiner-Fokkema, M.R.; van Spronsen, F.J. Infants with Tyrosinemia Type 1: Should phenylalanine be supplemented? JIMD Rep. 2015, 18, 117-124. [CrossRef] [PubMed] 